\title{
MATHEMATICAL MODELING OF THE ADHESION OF REINFORCEMENT WITH HIGH STRENGTH CONCRETE
}

\author{
Marek Dohojda', Sergiy Filipchuk ${ }^{2 \bowtie}$, Ruslan Makarenko ${ }^{2}$ \\ ${ }^{1}$ Institute of Civil Engineering, Warsaw University of Life Sciences - SGGW, Warsaw, Poland \\ ${ }^{2}$ Institute of Construction and Architecture, National University of Water and Environmental Engineering, Rivne, Ukraine
}

\begin{abstract}
The article presents the results of experimental researches of the bond between steel and high strength concrete. According to the results of the experiment planned, the regression equation can be used in aim to analyze an impact of specific factors on the limit stresses on the surface of concrete and a steel bar, as well as to normalize the limit stresses of the bond. The adequacy of the mathematical models of bonds to the experimental data has been proved by the statistical methods.
\end{abstract}

Key words: strength, steel, concrete, bond

\section{INTRODUCTION}

The bond between steel and concrete is an important quality of the reinforced concrete which defines its carrying capacity, hardness and crack resistance, and depends on a great number of factors: strength of concrete, type and diameter of a steel bar, length of bars in concrete, depth of concrete cover, nature of load, length of processes in time, granulometric composition of the mixture, nature of the aggregate, hardening conditions, position of the steel bars during concrete casting and others. In relation to this, the safety of anchoring a steel bar in reinforced concrete structures also depends on a number of factors which define its bond with concrete. Because of a great number of influencing factors, the task of investigating the bond between steel and concrete is complicated but at the same time very crucial (Dvorkin, Babich \& Zhitkowskij, 2017).

Today, a considerable expansion in the area of reinforced concrete structures, especially in fortifications, demands the application of high strength concrete of C70, C80 and higher classes (Babich, Babich, Fil- ipchuk \& Kovalchuk, 2016; Babich, Babich \& Polianovska, 2017).

Based on the above, the aim of the research is to find out the peculiarities of the bond between a steel bar and high strength concrete in aim to determine an appropriate characteristics of the bond strength. Due to the well-known fact that the concrete is an elastic-plastic material characterized by curvilinear diagrams of a mechanical state, it is necessary to choose the plans for receiving quadratic dependencies (quadratic mathematical model). The matrix of the Box-Behnken design corresponds to the abovementioned demands (Dvorkin, Dvorkin \& Zhitkovskij, 2011).

\section{MATERIAL AND METHODS}

In the planned experiment, the impact factors (independent variables) are assumed as: $x_{1}$ - diameter of the bars; $x_{2}$ - length of anchoring a steel bar (length of bars in the concrete); $x_{3}$ - depth of a concrete cover (Table 1). 
Dohojda, M., Filipchuk, S., Makarenko, R. (2021). Mathematical modeling of the adhesion of reinforcement with high strength concrete. Acta Sci. Pol. Architectura, 20 (3), 3-10. doi: 10.22630/ASPA.2021.20.3.20

Table 1. Conditions of planning of the experiment

\begin{tabular}{|c|c|c|c|c|c|}
\hline \multicolumn{2}{|l|}{ Factors } & \multicolumn{3}{|c|}{ Levels of variation } & \multirow{2}{*}{ Interval of variation } \\
\hline Geometrical quantity & Denotation & -1 & 0 & +1 & \\
\hline Diameter of bars $(d)[\mathrm{mm}]$ & $x_{1}$ & 12 & 16 & 20 & 4 \\
\hline Length of anchorage $\left(l_{b}\right)[\mathrm{mm}]$ & $x_{2}$ & $5 d$ & $10 d$ & $15 d$ & $5 d$ \\
\hline Depth of concrete cover $(c)[\mathrm{mm}]$ & $x_{3}$ & $1 d$ & $2 d$ & $3 d$ & $1 d$ \\
\hline
\end{tabular}

All factors have a high degree of controlability enabling to choose a given level of variation. For the diameter of the bars on the basic level of planning $(0)$, a diameter $16 \mathrm{~mm}$ have been assumed, and on the lower $(-1)$ and upper $(+1)$ levels -12 and $20 \mathrm{~mm}$, respectively (interval of variation equals $4 \mathrm{~mm}$ ). These diameters of the bars are the most common for reinforcement of the concrete.

Along with the main samples, six test cubes having the size of $150 \times 150 \times 150 \mathrm{~mm}$ were produced to determine the concrete cube strength after 28 days and within the period of testing the samples, six prisms having the size of $150 \times 150 \times 600 \mathrm{~mm}$ were produced to determine the concrete prism strength and initial module of elasticity after 28 days and within the period of testing the samples.

The average concrete cube strength $\left(f_{\text {cm,cube }}\right)$ after 28 days amounted to $70.4 \mathrm{MPa}$. The average concrete prism strength $\left(f_{c m, p r i s m}\right)$ for the assumed class of the concrete amounted to $58.8 \mathrm{MPa}$ (Hassan, 1977; Soretz, 1979; Bilosir, 1994; Ganga \& Hota, 2007; Babich, Polyanovska \& Demchuk, 2014).

In the researches being presented, a steel bar of A500C class and the diameter of 12, 16 and $20 \mathrm{~mm}$ was used, which is the most commonly used bar for concrete reinforcing. The Rehm index $\left(f_{R}\right)$ for these bars amounted to $0.070,0.075$ and 0.071 respectively, what corresponds to the average values providing a needed bond with concrete (Rehm, 1977, 1979).

The basic test samples were produced in the form of concrete prisms of square cross section, with sides equal to $15 \mathrm{~cm}$, and the height corresponding to the planned length of the anchorage. The steel bars were located in the prisms in such a way that their longitudinal axis matched together. The part of the bar protruding out of prisms allowed to grip it in the hydraulic press on the one side, and to measure their displacement relative to the end of the prisms on the other (free) side of the bars (Fig. 1). All the parameters of the samples were taken relatively to the matrix of the experimental design.

In each point of the design, three twin samples were produced, and on the basic level - six samples. Besides, concrete samples in the form of standard cubes and prisms were made to determine the compressive strength features of the concrete, as well as in the form of prisms to determine the tensile strength of the concrete. According to the design, 18 basic samples were tested in total. The samples were moulded in wooden forms where prior the steel bars had been placed.

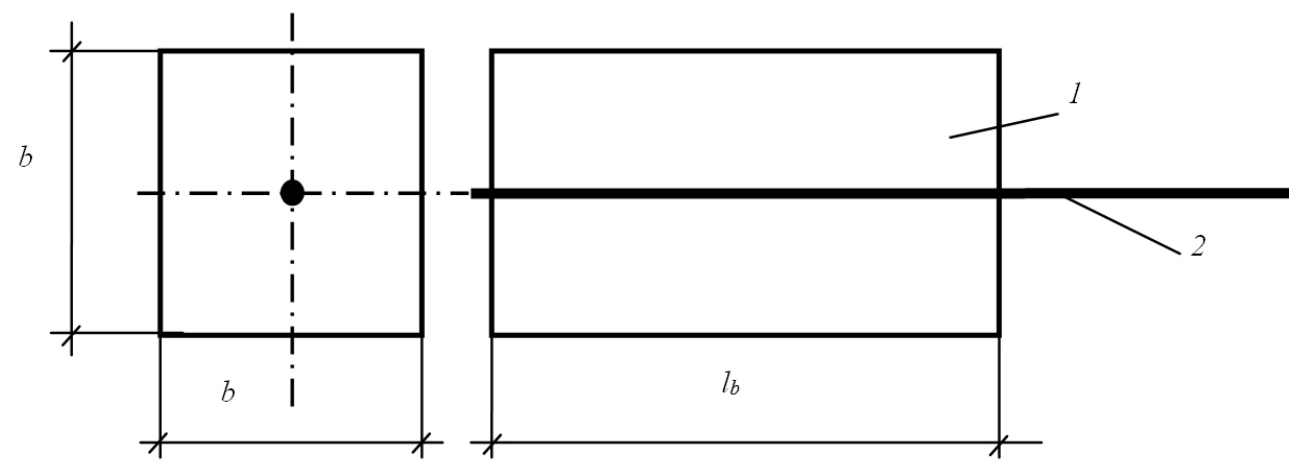

Fig. 1. Constructive scheme of the test samples: 1 - concrete prism; 2 - steel bar (Babich et al., 2017) 
Dohojda, M., Filipchuk, S., Makarenko, R. (2021). Mathematical modeling of the adhesion of reinforcement with high strength concrete. Acta Sci. Pol. Architectura, 20 (3), 3-10. doi: 10.22630/ASPA.2021.20.3.20

The researches of the bond between steel and concrete were carried out by means of pulling out the bars from the concrete prisms using a special reverse device in the tensile hydraulic machine UIM-50. The pulling force increased $(\Delta F)$ gradually, in steps equal to $(0.5, \ldots, 1.0) \mathrm{kN}$.

The limit state of the bond between steel and concrete was assumed as a force in the $\operatorname{bar}\left(F_{u}\right)$ in the moment when displacement of its free end relative to the end of the prism amounted $\delta_{u}=0.1 \mathrm{~mm}$ or the splitting of the prism at $\delta<0.1 \mathrm{~mm}$ happened (Fig. 2). In the limit state, maximum shearing stresses (bond stress) were defined and have been averaged over the length for each sample using a formula

$f_{b i}=\frac{F_{u i}}{\pi \cdot d \cdot l_{b}}$

where:

$f_{b i}-$ average limit bond stresses of an $i$-th sample on the contact surface between a bar and concrete,

$F_{u i}$ - breaking force of an $i$-th sample in the limit state,

$d$ - diameter of a bar,

$l_{b}-$ length of a bar in concrete (length of anchorage of a bar).

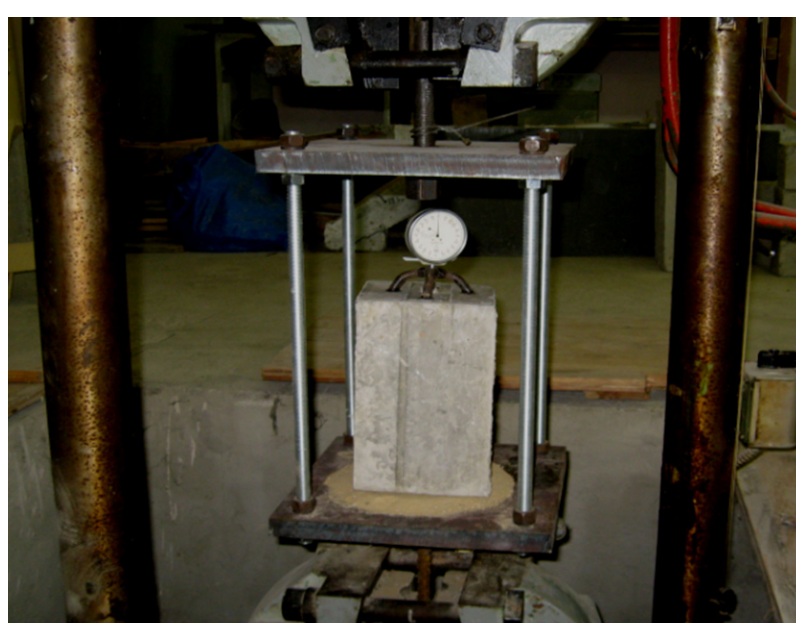

Fig. 2. General look of testing the samples

The limit average shearing stresses $\left(f_{b}\right)$, appearing on the contact surface between a bar and concrete and defined by the Eq. (1), can be called as the bond strength of a steel bar with concrete. The criterion of the strength is the displacement of the end of a $\operatorname{bar}(\delta)$ in concrete equal to $0.1 \mathrm{~mm}$ and more or splitting the concrete (Fig. 3).

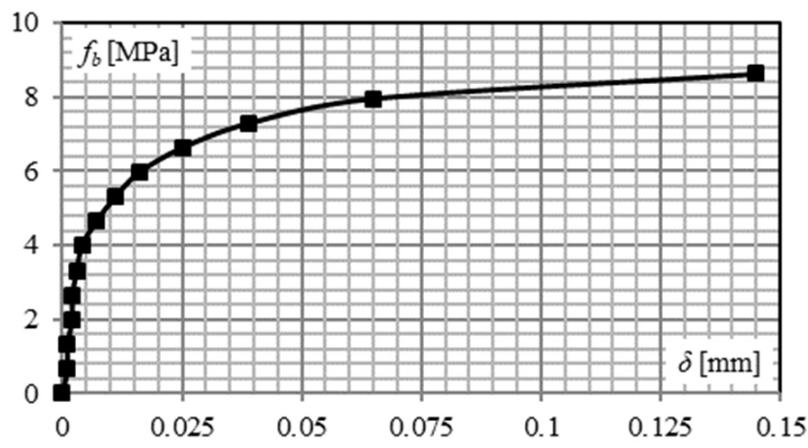

Fig. 3. Displacement of a free end of a bar depending on shearing stresses

\section{RESULTS OF THE RESEARCHES}

While testing the basic samples, the breaking forces $\left(F_{u i}\right)$ in the limit state were determined for each of them, and according to their values the values of the limit stresses $\left(f_{b i}\right)$ of the bond between bars and concrete on their contact as well as their average values $f_{b m}$ in each point of the design (Table 2) were determined.

On the basic level, basing on the results of testing six samples, the average maximum bond stresses $\left(f_{b m}\right)$ amounted to $11.22 \mathrm{MPa}$.

Complete quadratic equations of regressions describing maximum bond stresses base on the Eq. (2), given as follows (Dvorkin et al., 2011):

$$
\begin{aligned}
& f_{b}=b_{0}+b_{1} x_{1}+b_{2} x_{2}+b_{3} x_{3}+b_{11} x_{1}^{2}+b_{22} x_{2}^{2}+b_{33} x_{3}^{2}+ \\
& +b_{12} x_{1} x_{2}+b_{13} x_{1} x_{3}+b_{23} x_{2} x_{3}
\end{aligned}
$$

where $b_{0}, b_{i}, b_{i i}$ and $b_{i j}$ are free term of the regression equation and coefficients of linear and quadratic terms as well as interaction terms.

Coefficients of regression equations $b_{0}, b_{i}, b_{i i}$ and $b_{i j}$ for the three-level Box-Behnken design are determined statistically by the formulas: 
Dohojda, M., Filipchuk, S., Makarenko, R. (2021). Mathematical modeling of the adhesion of reinforcement with high strength concrete. Acta Sci. Pol. Architectura, 20 (3), 3-10. doi: 10.22630/ASPA.2021.20.3.20

Table 2. Matrix of the Box-Behnken design and initial experimental data

\begin{tabular}{cccccccc}
\hline \multirow{2}{*}{ Points of design } & \multicolumn{3}{c}{ Matrix of planning } & \multicolumn{5}{c}{ Initial parameters $\left(f_{b}\right)[\mathrm{MPa}]$} \\
\cline { 2 - 8 } & $x_{1}$ & $x_{2}$ & $x_{3}$ & $f_{b 1}$ & $f_{b 2}$ & $f_{b 3}$ & $f_{b m}$ \\
\hline 1 & +1 & +1 & 0 & 8.75 & 9.61 & 9.97 & 7.44 \\
2 & +1 & -1 & 0 & 7 & 8.91 & 7.16 & 7.69 \\
3 & -1 & +1 & 0 & 9.58 & 9.58 & 9.58 & 9.58 \\
4 & -1 & -1 & 0 & 7.5 & 6.32 & 8.84 & 7.55 \\
5 & +1 & 0 & +1 & 11.62 & 11.46 & 11.46 & 11.51 \\
6 & +1 & 0 & -1 & 10.03 & 10.9 & 10.19 & 10.37 \\
7 & -1 & 0 & +1 & 11.94 & 11.48 & 13.6 & 12.34 \\
8 & -1 & 0 & -1 & 9.62 & 9.75 & 9.75 & 9.71 \\
9 & 0 & +1 & +1 & 11.94 & 10.78 & 9.53 & 10.75 \\
10 & 0 & +1 & -1 & 9.53 & 9.55 & 10.53 & 9.87 \\
11 & 0 & -1 & +1 & 10.57 & 10.54 & 10.44 & 10.52 \\
12 & 0 & -1 & -1 & 9.12 & 8.7 & 9 & 8.94 \\
\hline
\end{tabular}

Note: In Points 1-12 of the design, three tests are performed; in Point 13 of the design, six tests (basic level) were done.

$b_{0}=\frac{\sum_{i=1}^{n_{0}} f_{b 0}}{n_{0}}$

$b_{i}=T_{3}\left(i f_{b}\right)$

$b_{i i}=T_{4}\left(i i f_{b}\right)+T_{5}\left(\sum_{i=1}^{3}\left(i i f_{b}\right)-T_{6}\left(0 f_{b}\right)\right.$

$b_{i j}=T_{6}\left(i j f_{b}\right)$

where:

$f_{b 0}-$ initial parameters on the zero level,

$n_{0}-$ number of tests on the zero level (number of zero points),

$i, j-$ numbers of tests (in tests $i=1, \ldots, 3$; $j=1, \ldots, 3)$,

$f_{b}-$ initial parameters (experimental data),

$T_{2}, T_{3}, T_{4}, T_{5}$ and $T_{6}$ - calculated values of the parameters defined for specific designs with use of methods of the mathematical statistics.
Based to the test results in the zero points, the absolute coefficient $\left(b_{0}\right)$, determined by the Eq. (2), appeared to be equal 11.22 MPa. Other coefficients were determined using Eqs. (3)-(6), where the parameters calculated in aim to determine these coefficients were found by the following formulas:

$\left(i f_{b}\right)=\sum_{1}^{N} x_{i} f_{b m}$

$\left(i i f_{b}\right)=\sum_{1}^{N} x_{i}^{2} f_{b m}$

$\left(i j f_{b}\right)=\sum_{1}^{N} x_{i} x_{j} f_{b m}$

$\left(0 f_{b}\right)=\sum_{1}^{N} x_{0} f_{b m}$

where $N$ is a number of points of the design.

For the three-level Box-Behnken design, the calculated values of $T$ are following: $T_{2}=0.1667 ; T_{3}=0.125$; $T_{4}=0.25 ; T_{5}=-0.0028 ; T_{6}=0.25$ (Babich et al., 2016). 
The values of the coefficients in the regression equations, calculated with the Eqs. (3)-(6) and (7)-(10) into account, are given in Table 3. For example:

$$
\begin{aligned}
b_{1} & =T_{3}\left(i f_{b}\right)=0.125 \cdot(-0.16)=-0.02 \\
b_{11} & =T_{4}\left(i i f_{b}\right)+T_{5}\left(\sum_{i=1}^{3}\left(i i f_{b}\right)-T_{2}\left(0 f_{b}\right)=\right. \\
& =0.25 \cdot 78.2-0.0028(78.2+74.34+84.01)- \\
& -0.1667 \cdot 118.28=-0.83 \\
b_{12} & =T_{6}\left(i j f_{b}\right)=0.25 \cdot(-0.27)=-0.07
\end{aligned}
$$

According to the value of the regression coefficients, a degree of an impact of the appropriate factor can be assessed. The coefficients are considered to be significant if the calculated value of Student's $t$-test appears to be higher than the tabular one, assumed depending on the given level of significance and number of degrees of freedom.

In aim to determine the calculated value of the Student's $t$-test for each coefficient of the regression equation, it is necessary to determine the mean-square deviation of an initial parameter and mean-square error. In the theory of planned experiments, a mean-square deviation can be determined according to the number of tests in the zero points $n_{0}$ and used for the whole experiment. In this case, the variation of test results in other points of the design is not taken into account, but it may differ from the variation in the zero points. It is true especially for reinforced concrete elements and, in particular, the concrete itself. Therefore, it is advisable to estimate the significance of the coefficient $b_{0}$ by the test results in the zero points, and all others - in all points of the design.

Considering the given mean-square deviation of the test results in the zero points $S_{\left\{f_{b 0}\right\}}$ and in other points of the design $S_{\left\{f_{b i}\right\}}$, they can be determined by formulas:

$S_{\left\{f_{b 0}\right\}}=\sqrt{\frac{\sum_{1}^{n_{0}}\left(f_{b 0 i}-f_{b 0 m}\right)^{2}}{n_{0}-1}}$
$S_{\left\{f_{b i}\right\}}=\sqrt{\frac{\sum_{1}^{N} \sum_{1}^{r}\left(f_{b i}-f_{b m}\right)^{2}}{N(r-1)}}$

where:

$n_{0}$ - number of tests in the zero points $\left(n_{0}=6\right)$,

$N$ - number of design rows except the zero points $(N=12)$,

$r-$ number of tests in a row $(r=3)$.

In order to determine the mean-square deviations by Eq. (12), firstly reconstruction variances were determined according to the rows of the design in a tabular form.

The mean-square deviations are determined by the formula:

$S_{\left\{f_{b i}\right\}}=\sqrt{\frac{\sum S_{\left\{f_{b}\right\}}^{2}}{N(r-1)}}=\sqrt{\frac{12.82}{12(3-1)}}=0.731$

In aim to find theoretical values of Student's $t$-test for each coefficient of the regression equation, it is necessary to determine the mean-square errors by formulas:

$S_{\left\{b_{0}\right\}}=T_{7} \cdot S_{\left\{b_{0}\right\}}$

$S_{\{b i\}}=T_{8} \cdot S_{\left\{f b_{i}\right\}}$

$S_{\left\{b_{0}\right\}}=T_{9} \cdot S_{\left\{f b_{i i}\right\}}$

$S_{\left\{b_{i j}\right\}}=T_{10} \cdot S_{\left\{f b_{i j}\right\}}$

where $T_{7}, T_{8}, T_{9}$ and $T_{10}$ are coefficients, which, for the three-level Box-Behnken design, are equal to $T_{7}=0.5774 ; T_{8}=0.3536 ; T_{9}=0.5204 ; T_{10}=0.5$.

According to the Eq. (13), the values of the mean-square errors turned out to be equal:

$$
\begin{aligned}
S_{\left\{b_{0}\right\}} & =0.5774 \cdot 0.308=0.178 \\
S_{\{b 1\}} & =S_{\{b 2\}}=S_{\{b 3\}}= \\
& =0.3536 \cdot 0.731=0.258 \\
S_{\{b 11\}} & =S_{\{b 22\}}=S_{\{b 33\}}=0.5204 \cdot 0.731=0.38 \\
S_{\{b 12\}} & =S_{\{b 13\}}=S_{\{b 23\}}= \\
& =0.5 \cdot 0.731=0.365
\end{aligned}
$$


Table 3. Coefficient values of the regression equations

\begin{tabular}{|c|c|c|c|c|c|c|c|c|c|}
\hline$b_{0}$ & $b_{1}$ & $b_{2}$ & $b_{3}$ & $b_{11}$ & $b_{22}$ & $b_{33}$ & $b_{12}$ & $b_{13}$ & $b_{23}$ \\
\hline 11.22 & -0.02 & 0.62 & 0.78 & -0.83 & -1.79 & 0.62 & -0.07 & -0.37 & -0.17 \\
\hline
\end{tabular}

Using the Eq. (11), the values of the mean-square deviation for the tests in the zero points were calculated and they were equal to $S_{\left\{f_{b 0}\right\}}=0.308$. The calculated values of the Student's $t$-test for each coefficient of the regression equation were found by the formulas (Dvorkin et al., 2011):

$$
\begin{gathered}
t_{\left\{b_{0}\right\}}=\frac{\left|b_{0}\right|}{S_{\left\{b_{0}\right\}}} \\
t_{\{b i\}}=\frac{\left|b_{i}\right|}{S_{\{b i\}}} \\
t_{\{b i i\}}=\frac{\left|b_{i i}\right|}{S_{\{b i i\}}} \\
t_{\{b i j\}}=\frac{\left|b_{i j}\right|}{S_{\{b i j\}}}
\end{gathered}
$$

The tabular values of the Student's $t_{m}$-test can be determined for the level of significance 0.05 depending on the number of degrees of freedom. For the coefficients $b_{0}$, the number of the degrees of freedom $\left(f_{\{b\}}\right)$ amounts to $n_{0}-1=6-1=5$, but for other coefficients equals $N(r-1)=12(3-1)=24$. Accordingly, the tabular Student's $t_{m}$-test value $\left(t_{m}\right)$ is 2.57 for the coefficient $b_{0}, 2.06$ for other coefficients.

Comparing the values of the calculated and tabular tests (Table 4), a conclusion can be drawn that the coefficients $t_{b 12}$ and $t_{b 22}$ must not be considered in the equation. For the coefficients in the quadratic terms, the values of the calculated coefficients are lower than the tabular ones, but for the quadratic terms it is not recommended to neglect coefficients of the regression equations (Dvorkin et al., 2011).
Ultimately, the regression equations which can be believed to be a mathematical model defining the limit stresses of the bond between concrete and steel bars on their contact surface, can be written in the following way according to the research results:

$$
\begin{aligned}
& f_{b}=11.22+0.62 x_{2}+0.78 x_{3}-0.83 x_{1}^{2}-1.79 x_{2}^{2}+ \\
& +0.62 x_{3}^{2}-0.37 x_{1} x_{3}
\end{aligned}
$$

The obtained regression equation adequately describes the results of the experimental researches, as the calculated value of the Fisher's $F$-ratio test is lower than the tabular value. The calculated value of the Fisher's $F$-ratio test was found by the formula:

$F_{p}=\frac{S_{\left\{f_{b}\right\}}^{2}}{S_{a d}^{2}}$

where $S_{\left\{f_{b}\right\}}^{2}$ is a reconstruction variance of the initial parameter which is evaluated by the formula:

$S_{\left\{f_{b}\right\}}^{2}=\frac{\sum_{1}^{N} \sum_{1}^{r}\left(f_{b i}-f_{b m}\right)^{2}}{N(r-1)}$

where:

$\sum_{1}^{N}-$ sum in matrix columns,

$\sum_{1}^{r}-$ sum in matrix rows,

$S_{a d}^{2}$ - variance of adequacy, defined by the formula.

Table 4. Values of the Student's $t$-test

\begin{tabular}{|c|c|c|c|c|c|c|c|c|c|}
\hline$t_{b 0}$ & $t_{b 1}$ & $t_{b 2}$ & $t_{b 3}$ & $t_{b 11}$ & $t_{b 22}$ & $t_{b 33}$ & $t_{b 12}$ & $t_{b 13}$ & $t_{b 23}$ \\
\hline 63.03 & 0.08 & 2.39 & 3.01 & 2.18 & 4.72 & 1.64 & 0.19 & 1.02 & 0.48 \\
\hline
\end{tabular}


$S_{a d}^{2}=\frac{r}{N-m} \sum_{1}^{N}\left(f_{b, t h e o r e t}-f_{b m}\right)^{2}$

where:

$m-\quad$ a number of significant coefficients in a regression equation $(m=7)$,

$f_{b, \text { theoret }}$ - calculated value of the initial parameter, defined by the Eq. (15),

$f_{b m}-$ initial parameter according to the results of the experimental researches.

Reconstruction variance of the initial parameter (limit stresses of the bond) according to the Eq. (18), is $S_{\left\{f_{b}\right\}}^{2}=0.534$.

According to Eq. (19), variance of the adequacy $\left(S_{a d}^{2}\right)$ appeared to be 1.06. According to the Eq. (16), the calculated value of the Fisher's $F$-ratio test $\left(F_{p}\right)$ equals to 1.98 . The tabular coefficient $\left(F_{m}\right)$ for the confidence level 0.95 with a greater degree of freedom than 24 and less than 6 equals to 2.55 . As the tabular test is larger than the calculated one, the derived regression equation adequately describes the obtained experimental data.
Equation adequacy can be confirmed by other statistical indicators (Table 5). The average ratio of the experimental values of the limit stresses of the bond between steel bars and concrete to the theoretical values $\left(f_{b} / f_{b \text {,theoret }}\right)$, defined by the Eq. (15), amounts to 0.997. The mean-square deviations are 0.04 and the coefficients of variation are 0.04 as well, what is lower than the permissible normalized indicator for the concrete 0.135 .

Therefore, the obtained regression equation (15) can be used to analyze an impact of individual factors on the limit stresses on the surface between concrete and steel, as well as to normalize the limit stresses of the bond.

\section{CONCLUSIONS}

According to th e results of the planned experiment, the regression equation (15) can be used to analyze an impact of the specific factors on the limit stresses on the surface between concrete and a steel bar, as well as to normalize the limit stresses of the bond. The adequacy of the mathematical models of bonds to the experimental data has been proved by the statistical methods.

Table 5. Statistical estimate of adequacy of regression equations

\begin{tabular}{lccc}
\hline Point of design & $f_{b m}$ & $f_{b, \text { theoret }}$ & $f_{b} / f_{b, \text { theoret }}$ \\
\hline 1 & 9.44 & 9.13 & 1.035 \\
2 & 7.69 & 8.03 & 0.958 \\
3 & 9.58 & 9.30 & 1.030 \\
4 & 7.55 & 7.93 & 0.952 \\
5 & 11.51 & 11.77 & 0.978 \\
6 & 10.37 & 10.22 & 1.015 \\
7 & 12.34 & 11.81 & 1.045 \\
8 & 9.71 & 10.26 & 0.946 \\
9 & 10.75 & 11.45 & 0.939 \\
10 & 9.87 & 9.89 & 0.998 \\
11 & 10.52 & 10.21 & 1.030 \\
12 & 8.94 & 8.65 & 1.033 \\
\hline Average value & & & 0.997 \\
\hline Mean-square deviation & & & 0.040 \\
\hline Coefficient of variation & & 0.040 \\
\hline
\end{tabular}




\section{REFERENCES}

Babich, E. M., Babich V. E., Filipchuk, S. V. \& Kochkarov, D. V. (2016). Mekhanichni harakteristiki shvidkotverdnuchih visokomicnih betoniv. In Resursoekonomni materiali, konstrukciï, budivli ta sporudi (pp. 114-120). Rivne: NUVGP.

Babich, E. M., Babich, V. E. \& Polianovska, O. E. (2017). Zcheplennya $z$ betonom armaturi serpopodibnogo profilyu ta iï ankeruvannya $v$ zginalnih zalizobetonnih elementah. Rivne.

Babich, V. E., Polyanovska, O. E. \& Demchuk, P. V. (2014). Doslidzhennya zcheplennya armaturi z betonom zalezhno vid tovshchini zahisnogo sharu. In Vipusk 28. Resursoekonomni materiali, konstrukciï, budivli ta sporudi: Zbirnik naukovih prac (pp. 105-111). Rivne: NUVGP.

Bilosir, W., Haidukow, E. \& Krapfenbauer, R. (1994). Festickeit und Rissfestickeit der Stahlfaserbetonbiegelemente mit Fasern aus Blechabfällen (Z1. AD/11067/1994). Wien.

Dvorkin, L. J., Babich, E. M., ZHitkovskij, V. V., Bordyuzhenko, O. M., Filipchuk, S. V., Kochkar'ov, D. V.,
Kovalik, I. V., Kovalchuk, T. V. \& Skripnik, M. M. (2017). Visokomicni shvidkotverdnuchi betoni ta fibro betony. Rivne: NUVGP.

Dvorkin, L. J., Dvorkin, O. L. \& ZHitkovskij, V. V. (2011). Rozvyazuvannya budivelno-tekhnologichnih zadach metodami matematichnogo planuvannya eksperimentu. Rivne: NUVGP.

GangaRao, H. V. S., Taly, N. \& Vijay, P. V. (2007). Reinforced concrete design FRP composites. London - New York: CRC Press.

Hassan, F. M. \& Hawkins, N. M. (1977). Prediction of the seismic loading anchorage characteristics of reinforced bars. ACJ Journal, February, 297-309.

Rehm, G. \& Eligehausen, R. (1977). Einfluss einer nicht ruhenden Belastung auf das verbundverhalten von Rippenstalen. Betonwerk + Fertigteil-Technik, 43, 295-299.

Rehm, G. \& Eligehausen, R. (1979). Bond Ribbed Bars under repeated loads. ACJ Journal, 76 (2), 297-310.

Soretz, S. \& Halzenbein, H. (1979). Influence of rib dimensions of reinforcing bars on bond and bendability. ACI Journal Proceedings, 76 (1), 111-128.

\section{MATEMATYCZNE MODELOWANIE PRZYCZEPNOŚCI ZBROJENIA Z BETONEM O DUŻEJ WYTRZYMAŁOŚCI}

\section{STRESZCZENIE}

W artykule przedstawiono wyniki badań eksperymentalnych wiązania stali z betonem o dużej wytrzymałości. Zgodnie z wynikami planowanego eksperymentu równanie regresji może być wykorzystane do analizy wpływu określonych czynników na naprężenia graniczne na powierzchni betonu i pręta stalowego, a także do normalizacji naprężeń granicznych wiązania. Adekwatność modeli matematycznych wiązań do danych eksperymentalnych udowodniono metodami statystycznymi.

Słowa kluczowe: wytrzymałość, stal, beton, spoiwo 